\title{
Somatotropic-Testicular Axis: A crosstalk between GH/IGF-I and gonadal hormones during development, transition, and adult age
}

\author{
Marta Tenuta $^{1}$ (D) | Francesco Carlomagno ${ }^{1}$ (D) | Biagio Cangiano ${ }^{2}$ (i) | \\ George Kanakis $^{3}$ (D) | Carlotta Pozza ${ }^{1}$ (D) | Emilia Sbardella ${ }^{1}$ (D) | Andrea M. Isidori ${ }^{1}$ (D) | \\ Csilla Krausz ${ }^{4}$ (D) | Daniele Gianfrilli ${ }^{1}$ (C)
}

${ }^{1}$ Department of Experimental Medicine, Sapienza University, Rome, Italy

${ }^{2}$ Department of Clinical Sciences and Community Health, University of Milan, Milan, Italy

${ }^{3}$ Athens Naval and Veterans Affairs Hospital, Athens, Greece

${ }^{4}$ Department of Experimental and Clinical Biomedical Sciences "Mario Serio",

University of Florence, Florence, Italy

\section{Correspondence}

Daniele Gianfrilli, Department of Experimental Medicine, Sapienza University of Rome, Viale Regina Elena 324, Rome 00161, Italy.

Email: daniele.gianfrilli@uniroma1.it

Funding information

Sapienza University of Rome

\begin{abstract}
Background: The hypothalamic-pituitary-gonadal (HPG) and hypothalamic-pituitarysomatotropic (HPS) axes are strongly interconnected. Interactions between these axes are complex and poorly understood. These interactions are characterized by redundancies in reciprocal influences at each level of regulation and the combination of endocrine and paracrine effects that change during development.

Objectives: To comprehensively review the crosstalk between the HPG and HPS axes and related pathological and clinical aspects during various life stages of male subjects. Materials and methods: A thorough search of publications available in PubMed was performed using proper keywords.

Results: Molecular studies confirmed the expressions of growth hormone (GH) and insulin-like growth factor-I (IGF-I) receptors on the HPG axis and reproductive organs, indicating a possible interaction between HPS and HPG axes at various levels. Insulin growth factors participate in sexual differentiation during fetal development, indicating that normal HPS axis activity is required for proper testicular development. IGF-I contributes to correct testicular position during minipuberty, determines linear growth during childhood, and promotes puberty onset and pace through gonadotropin-releasing hormone activation. IGF-I levels are high during transition age, even when linear growth is almost complete, suggesting its role in reproductive tract maturation. Patients with GH deficiency (GHD) and insensitivity (GHI) exhibit delayed puberty and impaired genital development; replacement therapy in such patients induces proper pubertal development. In adults, few studies have suggested that lower IGF-I levels are associated with impaired sperm parameters.

Discussion and conclusion: The role of GH-IGF-I in testicular development remains largely unexplored. However, it is important to evaluate gonadic development in children with GHD. Additionally, HPS axis function should be evaluated in children with urogenital malformation or gonadal development alterations. Correct diagnosis and prompt therapeutic intervention are needed for healthy puberty, attainment of complete gonadal development during transition age, and fertility potential in adulthood.
\end{abstract}




\section{KEYWORDS}

growth hormone, IGF-I, testicle, growth hormone deficiency, puberty, transition age

\section{1 | INTRODUCTION}

Growth hormone (GH) and insulin-like growth factor-I (IGF-I) receptors are present in gonads ${ }^{1}$ and can modulate the activity of sex hormones. ${ }^{2}$ The hypothalamic-pituitary-gonadal (HPG) and hypothalamic-pituitary-somatotropic (HPS) axes are more strongly interconnected than that generally perceived, working to fine-tune each other's activities. During puberty, GH secretion proportionally increases with sex hormone secretion, ${ }^{3-5}$ whereas in late adulthood, both total testosterone and $\mathrm{GH}$ secretions mutually decrease over time. ${ }^{6}$

Interactions between the two axes have not been entirely elucidated. The redundancy of reciprocal influences at each level of regulation, which changes during different developmental stages, and the combination of endocrine and paracrine effects make the crosstalk particularly complex. Although studies using animal models provide some insights, studies based on the in vivo effects of $\mathrm{GH}$ and IGF-I on gonadal development, steroidogenesis, and fertility report controversial findings.
In this review, we discuss physiological mechanisms of the crosstalk between HPG and HPS axes and their clinical presentation and implications in function of various stages during development from infancy through puberty, transition age and, finally, adult life stages of male subjects.

A computerized literature search was performed using the following keywords: "adolescence," "fertility," "GH," "ghrelin," "IGF-I," "Leydig cell," "puberty," "Sertoli cell," "spermatogenesis," "steroidogenesis," "testis," "testosterone," and "transition age." Keywords were properly combined with Boolean operators to optimize the search.

\section{2 | PHYSIOLOGY OF CROSSTALK: THE CHICKEN AND THE EGG}

The interaction between HPS and HPG axes is observed at various stages and is likely to be mutual. GH and IGF-I receptors are found in

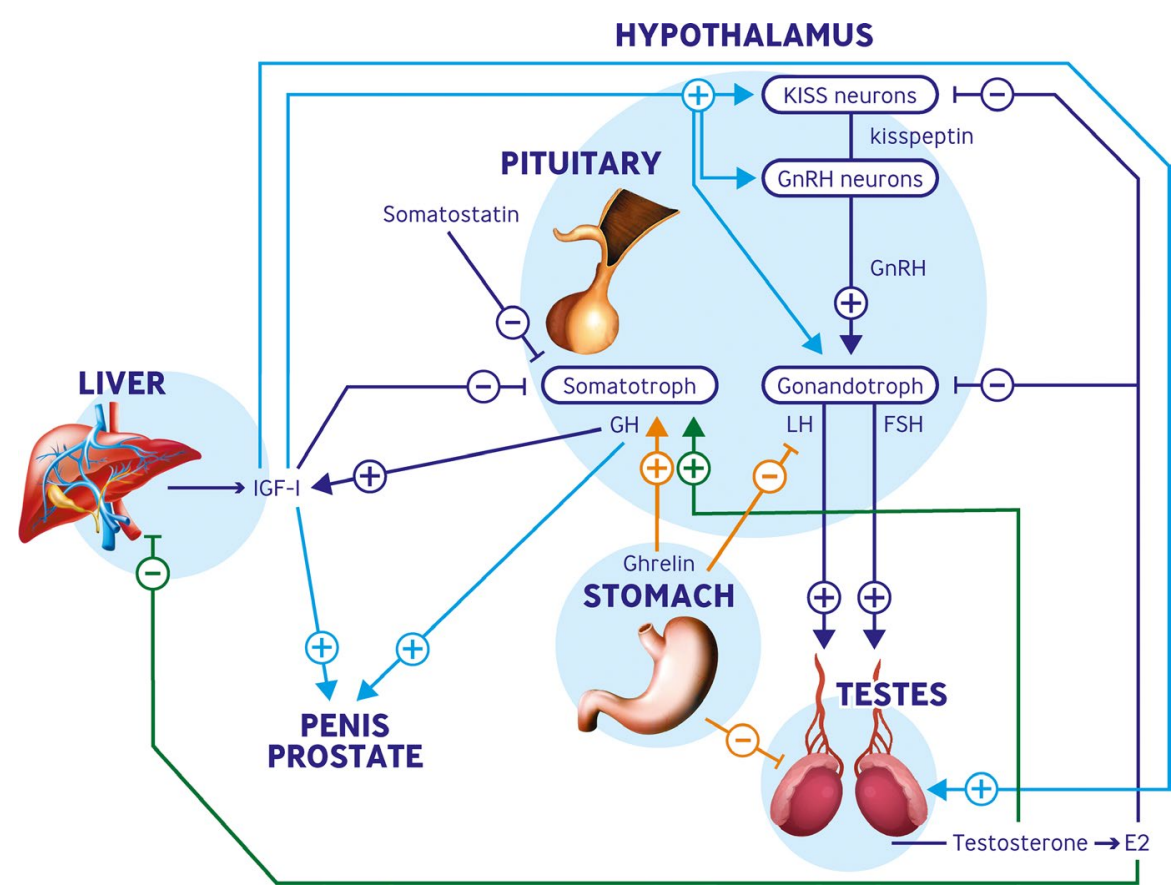

FIGURE 1 Schematic representation of the crosstalk between growth and gonadal hormones. Effects of growth on gonadal hormones (arrows in light blue): Pituitary somatotroph cells produce GH that stimulate liver to produce IGF-I. Somatostatin is the main negative regulator of GH secretion. IGF-I acts at many levels: (1) on hypothalamus activating GnRH neurons and kisspeptin neurons for puberty development, (2) on the pituitary gland activating gonadotroph cells, (3) on the testicles (for details, see Figure 2), and (4) on penis ad prostate probably influencing growth and development; GH can also directly act on prostate and penis. Effects of gonadal on growth hormones (arrows in green): FSH and LH released from gonadotroph pituitary cells directly stimulate the testicle (for details, see Figure 2); testosterone released from the testes and E2 trough aromatization are important facilitators of GH release from pituitary somatotroph cells; E2 is able to inhibit liver production of IGF-I. Effects of ghrelin (arrows in orange): Ghrelin is able to stimulate GH release from somatotroph cells and inhibits LH release from gonadotroph cells; moreover, ghrelin can act directly on the testes inhibiting both steroidogenesis and spermatogenesis (for details, see Figure 2) 
the reproductive tract, on gonadotropin-releasing hormone $(\mathrm{GnRH})$ neurons, and in pituitary gonadotroph cells. ${ }^{7-10}$ On the other hand, sex steroids act on the HPS axis for both neuroendocrine regulation of GHRH secretion and modulation of peripheral responsiveness to $\mathrm{GH}$. Because these reciprocal influences change during development, which axis acts first and which axis is dominant remain unclear. Acquiring knowledge on this issue has clinical implications, especially in terms of treatment. A summary of this complex crosstalk is presented in Figure 1.

\subsection{How GH and IGF-I influence the HPG axis}

GH and IGF-I have a central effect on hypothalamic GnRH neurons, kisspeptin neurons, and gonadotropin-secreting cells in the pituitary gland. Injection of IGF-I into rats, either centrally in the cerebrospinal fluid or peripherally, results in activation of the kisspeptin neurons in the anteroventral periventricular nucleus. ${ }^{11}$ Moreover, IGF-I seems to facilitate LH secretion from pituitary cells both in rats and in bovines. ${ }^{12-14}$

In mouse models, knockout (KO) of GH receptors (GHR) or IGFI or IGF-I receptor (IGF-IR) genes impairs sexual development and delays the onset of puberty. ${ }^{9,15,16}$ This phenotype overlaps with that observed in Kisspeptin1R KO mice, ${ }^{17}$ suggesting that IGF-IR signaling is vital for $\mathrm{GnRH}$ neuron maturation and synaptogenesis needed for pubertal onset. ${ }^{18}$ Although inhibition of systemic GH/IGF-I hormone levels does not prevent animals from achieving reproductive competence, a significant slowing down of gonadal development is observed, as detailed below. ${ }^{19,20}$ These findings suggest the existence of paracrine or alternative signals that keep receptor signaling active, although at a lower level.

The testis produces GH and IGF-I both in Leydig cells (LCs) and in Sertoli cells (SCS) (Figure 2). In the human testis, immunostaining for IGF-I is mainly observed in SCs and to a lesser extent in LCs. GHR and IGF-IR are expressed both by LCs and SCs as well as germ cells (primary spermatocytes, secondary spermatocytes and early spermatids). ${ }^{21}$ Testicular $\mathrm{GH}$, and more importantly, locally produced IGF-I generate many paracrine and autocrine signals involved in both spermatogenesis and steroidogenesis. This ultrashort paracrine loop appears to be controlled by FSH and LH, which stimulate IGF-I. ${ }^{22,23}$

The effect of IGF-I on steroidogenesis has been widely demonstrated. Administration of IGF-I alone in dwarf mice with growth hormone deficiency (GHD) has a mild effect on basal steroidogenesis, but it increases the number of hCG receptors on LCs, thereby indicating that IGF-I may potentiate gonadotropin-induced steroidogenesis. ${ }^{24}$ IGF-I also stimulates proliferation of LC progenitors and their differentiation. ${ }^{25}$ Similarly, $\mathrm{GH}$ enhances steroidogenic acute regulatory protein (StAR) and increases $3 \beta$-HSD gene expres$\operatorname{sion}^{26-28}$ in LCs.

As stated above, IGF-I may act as an autocrine factor for the regulation of spermatogenesis. Further, GHR-KO mice show reduced fertility, which supports this conclusion. However, spermatogenesis is not abolished, probably because of a $\mathrm{GH}$-independent production of IGF-I within the seminal tubules. ${ }^{29}$ In addition, IGF-I treatment increases sperm motility in the same mouse model. ${ }^{30}$

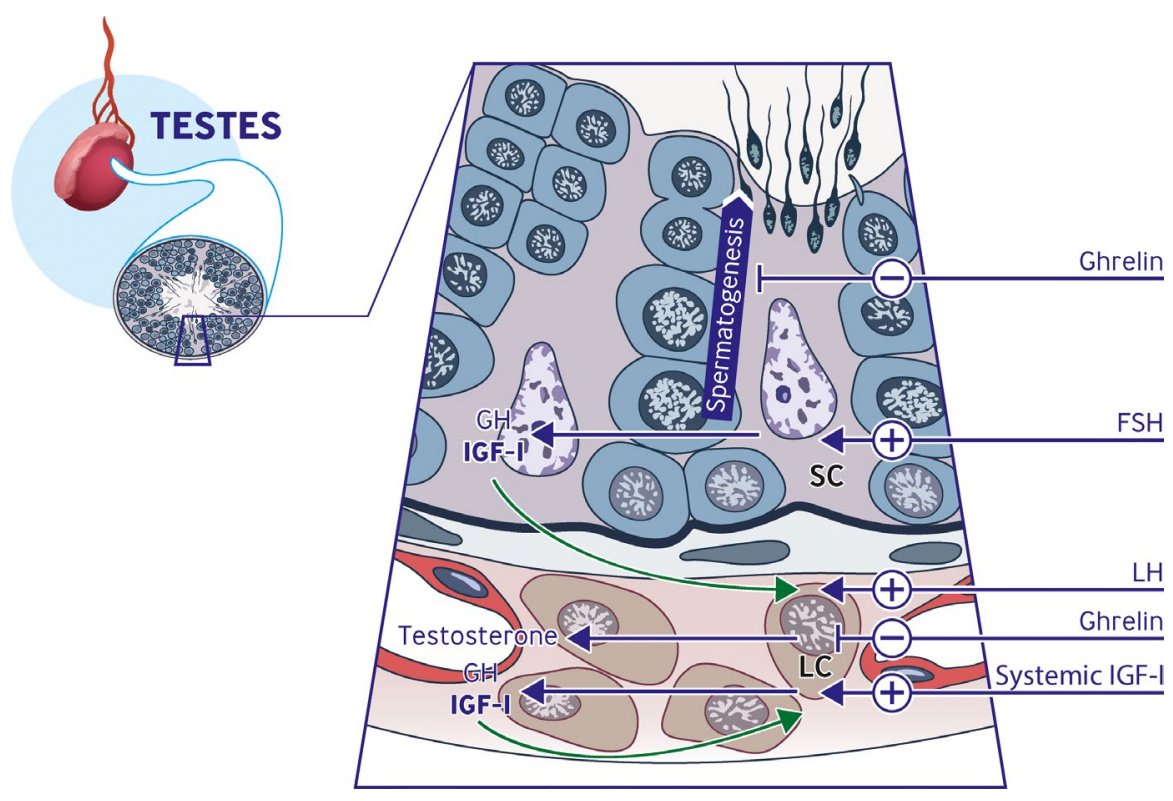

FIGURE 2 Schematic representation of the crosstalk between growth and gonadal hormones in the testis. Both Leydig (LC) and Sertoli cells (SC) are able to produce GH and-even more-IGF-I, under the control of FSH and LH. Ghrelin has an inhibitory function on growth hormone release from LC and SC and also on spermatogenesis. Locally produced IGF-I is able to generate many paracrine and autocrine signals involved in both spermatogenesis and steroidogenesis (arrows in green). Effects on steroidogenesis: IGF-I is also able to stimulate the proliferation of LC progenitors and their differentiation; GH enhances steroidogenic acute regulatory protein (StAR) and increases $3 \beta$-HSD gene expression in LC. IGF-I action on spermatogenesis is not yet fully confirmed and is not shown in the figure 


\subsection{How sex hormones can shape the HPS axis}

The influence of sex steroids on the somatotropic axis can be described by two major activities: central neuroendocrine regulation of $\mathrm{GH}$ secretion and peripheral modulation of $\mathrm{GH}$ responsiveness.

Testosterone and estradiol (E2) are important facilitators of $\mathrm{GH}$ secretion. Testosterone replacement therapy increases $\mathrm{GH}$ release by the pituitary gland in hypogonadal patients ${ }^{3,31}$ by increasing the amplitude of $\mathrm{GH}$ secretion bursts during puberty. ${ }^{32}$ This effect observed in these patients is due to testosterone and its aromatization to E2. Moreover, the role of estrogens is supported by impaired GH and IGF-I secretion ${ }^{33}$ in males with congenital aromatase deficiency.

Animal models have shown sex-related differences in sex hormone-driven somatotropic secretion. Male mice have more regular $\mathrm{GH}$ secretory pulses of high amplitude, whereas females show irregular secretory peaks of lower amplitude but higher interpulse $\mathrm{GH}$ levels. ${ }^{34,35}$ This sex-related effect seems to be mediated by somatostatin, the primary negative regulator of $\mathrm{GH}$ secretion, which exhibits a similar sex-specific secretion pattern. ${ }^{36-39}$ Studies in rats indicate that signal transduction may also contribute to the dimorphic effects of $\mathrm{GH}$ on growth. The rhythmic $\mathrm{GH}$ release typical in males is more efficient in activating the STAT5b signaling cascade, which when switched off in male STAT5b-KO rats, determines female-like growth despite the persistence of a male-like $\mathrm{GH}$ secretion pattern. ${ }^{40}$

Additionally, $\mathrm{GH}$ secretion in humans is sexually dimorphic: larger nocturnal pulses and relatively smaller daily pulses are observed in males than in females who display more continuous secretion and frequent irregular pulses. ${ }^{41}$ Sexual dimorphism in GH secretion likely contributes to differences in body growth: sex hormone levels during prepuberty are extremely low, and the HPS axis mediates skeletal growth without distinct differences between boys and girls. During puberty, sex hormones accelerate truncal growth more than appendicular growth until growth plate closure and cessation of growth. This process is principally mediated by E2, which explains why boys are taller than girls and display a longer growth period. ${ }^{42}$

Furthermore, the two sex hormones appear to influence the HPS axis also in adulthood. Testosterone positively modulates ghrelin, a hormone that stimulates $\mathrm{GH}$ release, in inducing higher $\mathrm{GH}$ bursts. ${ }^{43}$ Moreover, recent findings suggest that E2 is an important regulator of GH secretion in adult males. ${ }^{44}$ Pituitary receptors ER $\alpha$ and ER $\beta$ can synergistically act with the pituitary-specific transcription factor Pit1 to activate pituitary Gh gene transcription through high-affinity binding. ${ }^{45}$

Sex hormones also play a major role in regulating peripheral responsiveness to $\mathrm{GH}$, which is also gender related. In prepubertal age, both GH and IGF-I levels are comparable between boys and girls. ${ }^{46,47}$ Evidences from studies on adults show that GH circulating levels are lower in males than in females, which can be explained, at least in part, by higher $\mathrm{GH}$ clearance in males than in females owing to androgenic effects. ${ }^{46}$ IGF-I levels instead are higher in adult males ${ }^{48}$ than in females, also in GHD condition. ${ }^{49}$ This observation is mainly owing to the effect of E2 for lowering liver sensitivity to $\mathrm{GH}$ on the release of IGF-I. This is possibly the reason why males with GHD likely respond better to lower doses of $\mathrm{rhGH}$ with greater increases in IGF-I and bone mass than females. ${ }^{50,51}$ Similarly, normal ${ }^{49}$ or even acromegalic $^{52}$ females tend to show lower IGF-I/GH ratios than their male counterparts.

The underlying mechanism of lower GH sensitivity in females is the estrogenic upregulation of cytokine signaling-2 suppressors and/ or phospholipase $C$ (PKC) activation in the liver, ${ }^{53,54}$ both concurring to reduce Janus kinase 2 (JAK-2) phosphorylation and thus downregulate $\mathrm{GH}$ signal transduction. ${ }^{55}$ The final result is an E2-dependent inhibition of IGF-I secretion from hepatocytes.

\subsection{How the extratesticular effects of $\mathrm{GH}$ and IGF-I impact the reproductive system}

Apart from the above effects on testicular function, the HPS axis plays a role in the development of other reproductive organs. $\mathrm{GH}$ appears to be involved in penile growth in children because some studies have reported GHD- and GH-resistant subjects with reduced penis size, which was partially improved with $\mathrm{GH}$ therapy. ${ }^{56-58}$

Further, GH may have a beneficial role in erectile function, facilitating smooth muscle relaxation and reducing venous leakage, possibly through a stimulating effect on cyclic guanosine monophosphate (cGMP) generation in human cavernous smooth muscle. ${ }^{58}$ This biological mechanism was suggested through an in vivo human study that demonstrated that ED is associated with low levels of $\mathrm{GH}$ as well as NO and cGMP in cavernosal blood 59,60 .

Finally, an in vitro model of mouse organ cell cultures showed that anti-rGH antibody blocked Wolffian duct differentiation, specifically in the presence of fetal cells, and GH therapy reversed this condition. This observation indicates a possible role of GH/IGF-I in the fetal development of Wolffian duct-derived structures, such as the prostate and seminal vesicles, ${ }^{61}$ through an endocrine, a paracrine, or an autocrine mechanism that has not yet been defined.

The HPS axis has a more clearly defined role in adult prostatic disease: through its actions in promoting cell growth and survival, ${ }^{62,63}$ it appears to increase prostatic volume (PV), raising the risk of benign prostatic hyperplasia (BPH). GHD patients, in fact, show a reduced $\mathrm{PV},{ }^{64,65}$ while the opposite is true in acromegalic patients ${ }^{65,66}$ compared with healthy age-matched controls. In particular, in acromegaly, PV mostly correlates with duration of disease, rather than patients' age. ${ }^{65}$ Indeed, BPH is reported in approximately half the acromegalic subjects ${ }^{65,67}$ and the prevalence of parenchymal alterations (ie, cysts, calcifications and nodules) is also increased. ${ }^{65,66,68}$ Slight increase in PSA levels and International Prostate Symptom Scores (IPSS) are also reported in these patients, although prostatic symptoms are often absent. ${ }^{67,69}$ Moreover, as results from a large population study, prostatic cancer ( $\mathrm{PCa}$ ) incidence is increased both in healthy individuals with IGF-I levels in the upper reference range ${ }^{70,71}$ and in acromegalic patients. ${ }^{72}$ However, a recent meta-analysis of 23 studies in acromegaly reveals some potential sources of bias in the association between acromegaly and PCa: for example, cancer incidence was more 
pronounced in smaller and single-center studies (selection bias) and the enlarged PV in acromegaly may lead to more frequent US examination (diagnostic workup bias). ${ }^{73}$

In GHD patients, replacement therapy restores prostate size to normal, with no increase in prostate abnormalities or PSA levels; an even greater increase in $\mathrm{PV}$ is observed in hypogonadal patients also receiving concurrent testosterone replacement therapy. ${ }^{64}$ On the other side, effective pharmacological treatment of acromegaly for 1-2 years via somatostatin analogs results in a reduction of PV in young subjects ( $<50$ years old), but not in older ones, despite a rise in testosterone levels. ${ }^{66,74}$

\section{4 | The additional control level: ghrelin}

Ghrelin, which is among the primary activators of the HPS axis, is a peptide produced by the stomach that increases food intake and decreases energy consumption. Upon binding of its receptor, the $\mathrm{GH}$ receptor-secretagogues (GHS-R) ghrelin potently stimulate $\mathrm{GH}$ release. Ghrelin is found in the human testis in both interstitial LCs and also SCs, even if in lower amounts. GHS-R is detectable in germ cells, mainly pachytene spermatocytes, and in somatic SCs and LCs. ${ }^{75}$ Ghrelin has been proposed to link the neuroendocrine system and somatic growth with metabolism and reproduction. ${ }^{76}$

Ghrelin acts centrally, inhibiting LH production, and peripherally, reducing testosterone synthesis (Figure 1). In addition, ghrelin exerts a negative effect on germ cell development and LC proliferation ${ }^{77}$ (Figure 2) through the inhibition of the gene encoding stem cell factor (SCF), a c-Kit ligand, ${ }^{78,79}$ with implications on extragonadal effects of $\mathrm{GH}$, such as cardiovascular function. ${ }^{80,81}$ Thus, the hormone may act as an inhibitor of spermatogenesis and steroidogenesis. Evolutionarily, this action could depend on the need to inhibit reproductive function under conditions of fasting, underweight, and inadequate calorie uptake: ghrelin, indeed, is found at high levels under all these conditions. ${ }^{76}$ Likewise, leptin, an adipose tissue-derived anorexigenic hormone, acts on the reproductive tract, and its receptors are indeed expressed in the gonads. ${ }^{82-84}$ Leptin mainly acts as a permissive factor in the hypothalamus, where a minimum level is required for normal HPG axis activity; however, at higher levels, it inhibits LC steroidogenesis. ${ }^{85}$

In summary, fertility appears to be strictly linked to metabolic balance through leptin and ghrelin, and its full potential is achieved only in favorable nutritional environment after the completion of the transition age.

\section{3 | GROWING UP: FROM SEXUAL DIFFERENTIATION TO TRANSITION AGE}

\section{1 | Fetal development and infancy}

The interaction between the HPS and HPG axes starts in the first weeks of gestation, during which IGF-I and insulin-like family of growth factors play important roles in gonadal development and sexual differentiation. ${ }^{86} \mathrm{XY}$ mice KO for Igf1r and Insr show reduced expression of Sry and lack of activation of some genes crucial for testicular differentiation, such as Sox9, Fgf9, and Ptgds. SCs and LCs fail to develop as a result. ${ }^{87} \mathrm{~A}$ second study by the same group showed that selective Igf1r-Insr inactivation in SC impairs their proliferation during late fetal and early neonatal development, resulting in smaller testes and lower sperm output later in life. ${ }^{88}$ However, mutant mice are fertile, demonstrating that the absence of IGF-I signaling restricted to $\mathrm{SC}$ does not have a severe effect on spermatogenesis. Lower testes volume is likely to be related to reduced SC number. Notably, FSH amplifies IGF-I-mediated PI3K/AKT protein kinase signaling in $\mathrm{SC}$, highlighting the importance of this signal for SC proliferation. ${ }^{89}$

Shortly after birth, GnRH activation stimulates gonadotropin secretion as well as testosterone, inhibin B, and anti-Müllerian hormone $(\mathrm{AMH})$ production in boys. This process, called minipuberty, occurs approximately between months 1 and 6 of postnatal life: a rise in testosterone levels is considered responsible for greater linear growth observed in males than in females. ${ }^{90}$ This effect is synchronous with that of the activation of the HPS axis; IGF-I also increases shortly after birth and continues to escalate linearly until puberty. ${ }^{91}$

A recent study attributes a permissive role to IGF-I during minipuberty, along with LC and SC function, in consolidating testicular position in the scrotum to a low-enough location from which the testes are unlikely to ascend to high scrotal or suprascrotal position during childhood. ${ }^{92}$ IGF-I levels during minipuberty strictly correlate with testicular distance to the pubic bone (TDP) and thus with a lower testicular location in a linear mixed-effect model. ${ }^{92}$ After minipuberty, IGF-I levels slowly and linearly increase throughout infancy as a function of insulin levels and nutritional status. ${ }^{91}$ After the first year of life until late childhood, a deceleration of height velocity growth is observed, which is reversed only when puberty starts.

\section{2 | Puberty and transition age}

The GnRH pulse generator is activated at pubertal onset to trigger the hormonal cascade necessary for sexual maturation. This activation is strictly related to body mass and nutritional state; thus, anabolic hormones such as insulin and IGF-I contribute to GnRH pulsatiliy. ${ }^{9}$ At the same time, the amplitude of $\mathrm{GH}$ secretion bursts increases, along with the overall daily output of pituitary $\mathrm{GH}^{32}$ Both are needed for linear and pubertal development.

Mechanisms underlying HPS axis activation during puberty are not entirely clear but likely involve augmented hypothalamic release of GHRH mediated by testosterone surge ${ }^{93}$; kisspeptin neurons that activate pituitary somatotroph cells and increase their sensitivity to $\mathrm{GHRH}$ stimulation ${ }^{80}$ are also likely to be involved.

Transition age is defined as the phase between the end of puberty and young adulthood. The beginning of transition corresponds to the 
achievement of Tanner stage $\mathrm{V}$, while the end of transition corresponds to the achievement of peak bone mass. ${ }^{94}$ Transition age is therefore a crucial period as of the maturation of HPG and HPS axes ${ }^{95}$ and their mutual influence is especially relevant during this period.

IGF-I progressively increases in Tanner stages from I to III, concomitantly with the increase in testicular volume and then decreases during Tanner stages IV and V. ${ }^{47}$ These observations are confirmed by analysis of both bioavailable IGF-I and free IGF-I levels, ${ }^{96,97}$ thus excluding confounding factors. As recently highlighted in a short review by Juul and Skakkebaek, IGF-I levels usually peak 2 years after pubertal spurt, but the levels remain elevated for few years afterward, suggesting that GH and IGF-I are important for longitudinal growth but likely play a role in full maturation of the reproductive system. $^{98}$

As a matter of fact, HPS axis activation is needed for proper pubertal onset and maturation. For example, higher levels of serum IGF-I at 8 years of age are associated with early menarche in normal girls, even after adjustment for BMI, height, and prepubertal state. ${ }^{99}$ Moreover, girls with central precocious puberty have markedly elevated IGF-I levels compared with prepubertal peers, and their IGF-I levels gradually return to prepubertal levels after linear growth ceases or following GnRH agonist therapy. ${ }^{100}$ An interesting retrospective study conducted on prepubertal boys with constitutional delays in growth and puberty (CDGP) ${ }^{101}$ suggests a correlation between the degree of HPS axis activation and pubertal initiation. Lowest IGF-I levels were found in patients with hypogonadotropic hypogonadism, whereas highest IGF-I levels were found in patients with an early puberty. Taken together, these studies suggest an important role of the HPS axis in the physiological activation of the HPG axis (Table 1).

Conversely, HPS axis impairment during childhood and puberty can affect genital development. Conditions such as micropenis, ${ }^{102,103}$ hypospadias, and cryptorchidism ${ }^{104}$ frequently occur in patients with isolated GHD. Patients with Laron syndrome, GH insensitivity (GHI) due to a mutation in GH-receptor ${ }^{105}$ or STAT5 $5 b^{106}$ genes, offer an ideal model to study this crosstalk. All affected patients have delayed pubertal onset and a prolonged pace. ${ }^{107,108}$ Interestingly, treatment with recombinant human IGF-I (rhIGF-I) stimulates testicular and penile growth in these boys. ${ }^{109,110}$ Similarly, delayed puberty was observed in a 15-year-old boy born short for gestational age who harbored a mutation in the IGF-1 gene ${ }^{111}$ and in patients with mutations in genes encoding for other components of the HPS axis, such as IGF-2, ${ }^{112}$ IGF-1R, ${ }^{113}$ and $A L S^{114}$ (Table 2). Several studies on rhGH therapy in boys with GHD have reported faster progression of pubertal maturation ${ }^{115}$ compared with those with untreated GHD. Boys with GHD more frequently exhibited delayed puberty. ${ }^{116-120}$ In treated patients, age at onset of spontaneous puberty positively correlated with the commencement of $\mathrm{GH}$ therapy, as observed in 319 boys with idiopathic and non-congenital GHD. ${ }^{121}$

A retrospective study examined 37 prepubertal children (boys and girls) with congenital isolated growth hormone deficiency ${ }^{122}$ who were treated with rhGH. The authors observed delayed pubertal onset to be more evident in boys with age at first ejaculation occurring 3.5-4 years later than in the reference population. ${ }^{123}$
The authors once more suggested a positive correlation between age at initiation of treatment and age at pubertal onset. Stretched penile length at the end of puberty was shorter than that of the reference population average, although it significantly increased following rhGH therapy. ${ }^{56-58}$ Testicular volume was normal at the end of therapy, positively correlating with treatment duration and negatively with age at initiation of treatment. Age at first ejaculation was significantly higher than that in normal boys, and rhGH therapy induced a greater increase in testicular volume in patients who started therapy before 10 years of age; these observations emphasize that rhGH promotes pubertal development, even if it does not normalize it. These studies appear to confirm that better responses on puberty and sexual differentiation result when replacement therapy is promptly started at an early age. However, no clear evidence emerges on the correlation with treatment duration or dosage. One study observed a negative correlation between $\mathrm{GH}$ dose and pubertal onset but no correlation with treatment duration. ${ }^{124}$ In addition, a more recent study that evaluated pubertal onset in $111 \mathrm{GHD}$ children aged 3-16 years after 48 months of rhGH administration at different doses $(25,50$, and $100 \mu \mathrm{g} / \mathrm{kg} /$ day $)$ did not find any significant differences, even if the wide age range of inclusion and lack of control group may bias the findings ${ }^{125}$ (Table 1).

It remains controversial whether sex steroid priming during pubertal development improves the specificity of $\mathrm{GH}$ stimulation test for GHD diagnosis, thus reducing false-positive results. However, adjusted data on cut-off values post-priming are missing, and therefore, no clear consensus exists regarding the use of sex steroids outside of delayed puberty. ${ }^{126}$

Apart from children with GHD, rhGH is also used in children affected by idiopathic short stature (ISS). Data on the onset and pace of puberty and/or genital development after therapy in this setting are conflicting (Table 1). Some studies showed that treated children, as opposed to control patients, have an earlier pubertal onset and/ or pace of puberty ${ }^{127,128}$ and faster progression of bone age. Kawai et $\mathrm{al}^{128}$ in a small population treated with $24 \mu \mathrm{g} / \mathrm{kg} / \mathrm{day}$ of $\mathrm{rhGH}$ and Kamp et al in a larger ( 26 boys) population ${ }^{127}$ randomized to receive $70 \mu \mathrm{g} / \mathrm{kg} /$ day of rhGH for 2-4 years before puberty or no treatment, observed that a prepubertal exposure to $\mathrm{rhGH}$ can accelerate pubertal development.

Nevertheless, a number of larger studies found no effects. ${ }^{129-132}$ A controlled study of 91 boys with ISS randomized to receive rhGH or no therapy reported no differences in the timing of pubertal onset, age at which maximum mean testicular volume was reached, or duration of puberty in the treated population. However, at the end of puberty, significantly larger testicular volume was observed in $\mathrm{GH}$-treated boys than in controls, but smaller testicular volume was observed in $\mathrm{GH}$-treated boys than the expected value when compared to that of the national reference population. ${ }^{130}$ Other studies observed no difference in age at pubertal onset, pace of pubertal progression, ${ }^{131}$ or duration of puberty in $\mathrm{GH}$-treated boys compared with untreated subjects, even across different dosages ${ }^{132}$

Finally, results of a large multicentric study ${ }^{129}$ showed that different replacement regimens do not seem to influence pubertal 


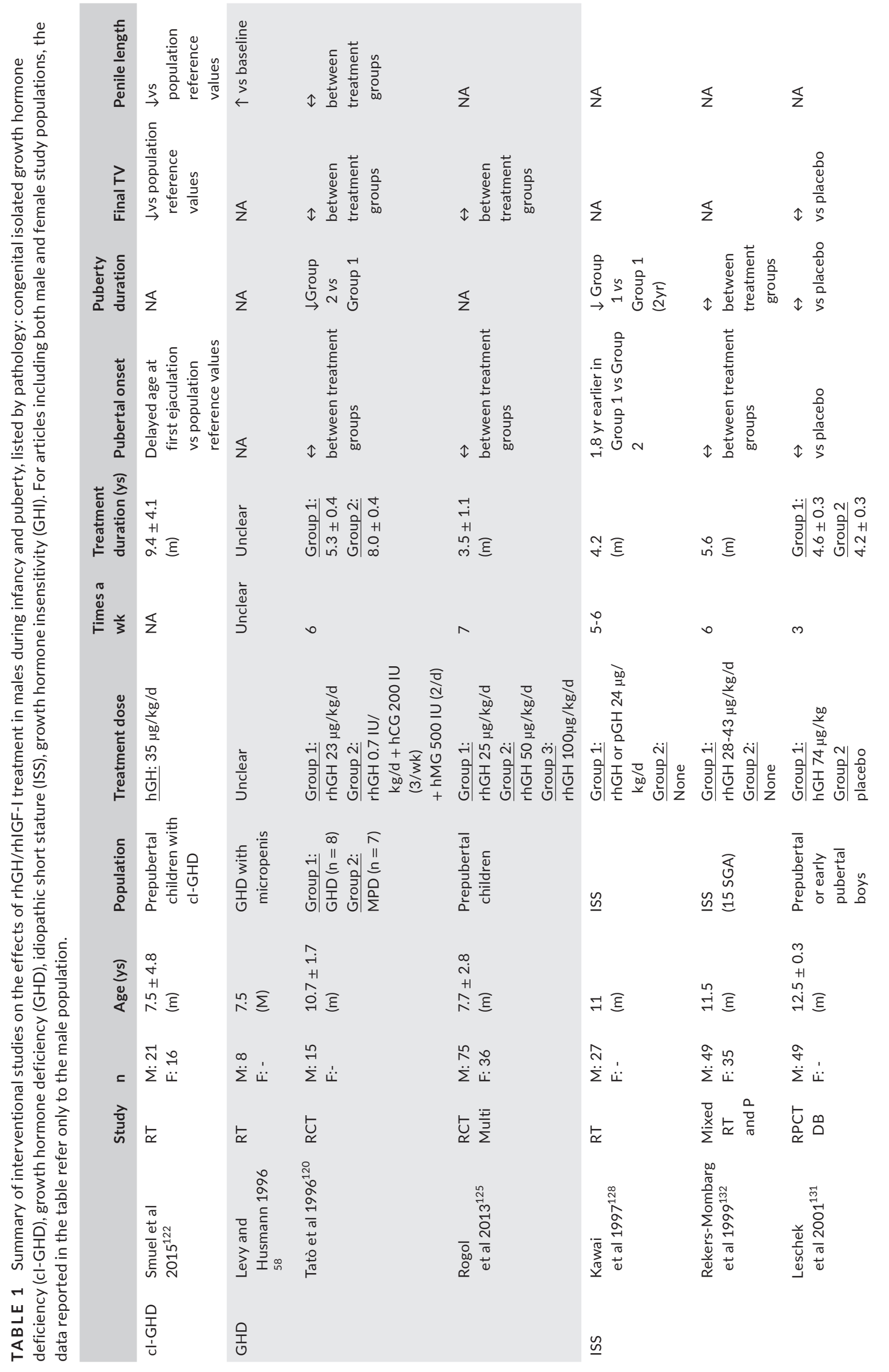




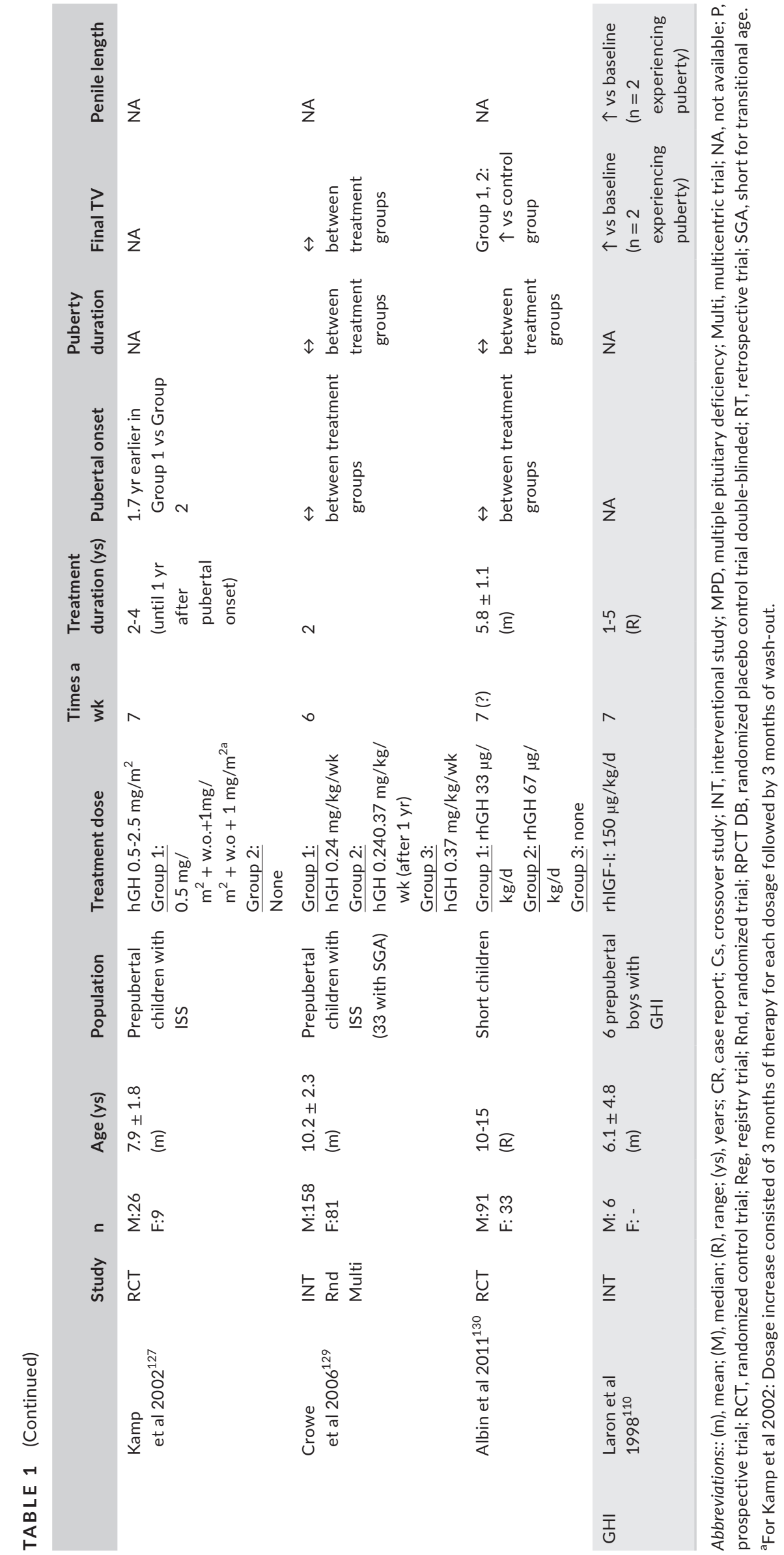


TABLE 2 Case reports of mutation in genes associated with GH insensitivity presenting with impaired genital development and puberty

\begin{tabular}{|c|c|c|c|c|c|c|}
\hline & $\mathrm{n}$ & Mutation & $\begin{array}{l}\text { Age at } \\
\text { diagnosis (ys) }\end{array}$ & $\begin{array}{l}\text { Growth } \\
\text { (height SDS) }\end{array}$ & Clinical presentation & Genital characteristics \\
\hline $\begin{array}{l}\text { Castilla-Cortazar } \\
\text { et al } 2017^{103}\end{array}$ & M: 1 & $\begin{array}{l}\text { IGF1R (hom) \& } \\
\text { IGFALS (het) }\end{array}$ & 14.8 & -14 & $\begin{array}{l}\text { VLBW (born at } 26 \text { wks of gestation) } \\
\text { Respiratory difficulties at birth }\end{array}$ & $\begin{array}{l}\text { Micropenis } \\
\text { Hypospadias } \\
\text { Tanner stage I }\end{array}$ \\
\hline $\begin{array}{l}\text { Kofoed et al } \\
2003^{106}\end{array}$ & $\mathrm{~F}: 1$ & STAT5b (hom) & 16.5 & -7.5 & $\begin{array}{l}\text { VLBW (born at } 33 \text { wks of gestation) } \\
\text { Facial dysmorphism } \\
\text { Respiratory difficulties at birth } \\
\text { Failure to thrive } \\
\text { Lymphoid interstitial pneumonia } \\
\text { Severe hemorrhagic varicella, } \\
\text { Recurrent herpes zoster } \\
\text { Pneumocystis carinii pneumonia }\end{array}$ & $\begin{array}{l}\text { Delayed puberty } \\
\text { Tanner stage III }\end{array}$ \\
\hline $\begin{array}{l}\text { Walenkamp } \\
\text { et al } 2005^{111}\end{array}$ & M: 1 & IGF1 (hom) & $55 \mathrm{yr}$ & -8.6 & $\begin{array}{l}\text { VLBW (born at } 32 \text { wks of gestation) } \\
\text { Failure to thrive } \\
\text { Microcephaly } \\
\text { Deaf-mutism } \\
\text { Motor unrest } \\
\text { IQ }<40 \\
\text { Arterial hypertension } \\
\text { Bilateral cataract } \\
\text { Severe osteoporosis }\end{array}$ & $\begin{array}{l}\text { Small penis } \\
\text { Delayed puberty } \\
\text { (pubarche and } \\
\text { gonadarche at } 20 \mathrm{yrs} \\
\text { of age) }\end{array}$ \\
\hline $\begin{array}{l}\text { Begemann } \\
\text { et al } 2015^{112}\end{array}$ & $\begin{array}{l}M: 2 \\
F: 2\end{array}$ & IGF2 (het) ${ }^{a}$ & $7.1(\mathrm{~m})$ & $\mathrm{R}:-1.6,-4$ & $\begin{array}{l}\text { (V)LBW } \\
\text { SRS-like facial dysmorphism } \\
\text { Feeding difficulties during infancy } \\
\text { Ulnar ray defects } \\
\text { High-pitched voice } \\
\text { Intellectual disability }\end{array}$ & $\begin{array}{l}\text { Delayed puberty } \\
\text { Hypospadias } \\
\text { Cryptorchidism }\end{array}$ \\
\hline $\begin{array}{l}\text { Gannagé-Yared } \\
\text { et al } 2013^{113}\end{array}$ & $\mathrm{~F}: 1$ & IGF1R (hom) & $13.5 \mathrm{yr}$ & -4.4 & $\begin{array}{l}\text { LBW (born at } 41 \text { wks of gestation) } \\
\text { Facial dysmorphism } \\
\text { Mild intellectual disability } \\
\text { Cardiac malformations } \\
\text { High-pitched voice } \\
\text { Acanthosis nigricans } \\
\text { Hypertriglyceridemia }\end{array}$ & Delayed puberty \\
\hline
\end{tabular}

Abbreviations:: (V) LBW, (very) low birthweight; F, female; het, heterozygosis; hom, homozygosis; IQ, intelligent quotient; M, male; m, mean; R, range; SRS, Silver-Russell syndrome; ys, years.

${ }^{a}$ IGF-2 is a maternally imprinted gene.

development. In 158 prepubertal boys, randomized to receive 34 or $74 \mu \mathrm{g} / \mathrm{kg} /$ day, no differences were found in age at onset, duration, or testicular volume during pubertal development between the two groups (Table 1).

Despite transition age being a crucial period for the full maturation of the reproductive system, few data are available for this specific age range. One report of four males aged 17-25 years treated with rhGH for ISS ${ }^{133}$ showed reduced testicular volume, hypergonadotropic hypogonadism, and impaired spermatogenesis. These findings were not replicated in other studies, thus allowing to exclude a detrimental effect of rhGH therapy on male gonadal function. A large study involving 111 boys treated with rhGH for GHD or ISS ${ }^{134}$ for at least 4 years and in which treatment began at least 1 year before pubertal onset showed normal testicular size and normal serum testosterone levels. Similar results have been reported in another study on eight young males aged $16-18$ years previously treated with rhGH for ISS or CDGP ${ }^{135}$ evidenced by normal testicular volume and endocrine function as well as mostly "normal" semen parameters at follow-up.

In conclusion, published data are very heterogeneous. Some studies were conducted in children with known congenital or acquired GHD and others in ISS children without GHD. Additionally, some boys were treated during infancy, whereas others were treated just before or during puberty. Combining all data, it can be concluded that a minimum HPS axis basal activity is needed to achieve most HPG effects on sexual maturation, but once this is achieved, additional doses of exogenous $\mathrm{GH}$ do not provide any additional benefit. Another limitation of the available studies is that the criteria for idiopathic GHD diagnosis varied with respect to the provocative test(s) and serum GH cut-off(s) used or with respect to sex steroid priming. An alternative hypothesis is that $\mathrm{GH}$ has a narrow time- and dose-dependent window for effects on puberty. Time dependency 
is suggested by the correlation between the age at which therapy starts and the age of pubertal onset in patients with GHD. ${ }^{127}$ Dose dependency is supported by positive results of some studies not definitively refuted by Crowe et al. ${ }^{129}$ In this regard, recent guidelines ${ }^{136}$ define therapeutic dosages in a range of $22-35 \mathrm{mcg} / \mathrm{kg} / \mathrm{day}$ for GHD and 34-67 mcg/kg/day for ISS. However, these ranges are established considering linear growth as the main outcome and not gonadal development. In several studies examined so far, higher doses were used instead because the aim was to observe possible effects on gonadal development. Standardization of dosages in this context would help to obtain more homogeneous results.

Finally, most studies did not employ proper control groups of untreated children, examined broad age ranges (ie, enrolled both prepubertal and pubertal children), and most importantly, were not adequately powered to clarify the role of rhGH therapy in pubertal pathophysiology.

\section{4 | THE GROWN-UP: CROSSTALK IN THE YOUNG ADULT}

Crosstalk between HPS and HPG axes is essential for sexual maturation during growth, but evidence in adult life is fragmentary and inconclusive. Sample sizes are often very low. Most studies included less than 10 patients, ${ }^{137-142}$ and larger studies were retrospective and observational. ${ }^{143,144}$ Few available prospective interventional studies were often under-powered and used very different protocols. Some trials focused on patients with $\mathrm{GHD}^{139,144-146}$ (post-surgical, adult GHD, childhood-onset GHD, and panhypopituitarism) and others on infertile males ${ }^{137,138,147-149}$ (oligoasthenoteratozoospermia, azoospermia, and idiopathic infertility) as well as on hypogonadal patients. ${ }^{140,142}$ Most studies addressed GHD and only few addressed $\mathrm{GH}$ excess. A report on reproductive function in acromegalic males showed lower androgen concentration and sperm parameters that improved after pharmacological or surgical control of the disease. ${ }^{150}$ This observation is consistent with that of animal studies. ${ }^{151}$

$\mathrm{GH}$ replacement studies used different durations and dosages that do not permit the determination of whether non-significant results could be owing to insufficient treatment duration or insufficient dose regimen.

Furthermore, $\mathrm{GH}$ therapy was often associated with gonadotropin treatment, ${ }^{137-140}$ masking the effects ascribed to one or the other replacement. Finally, outcomes of interest were not homogeneous. Some studies evaluated only sperm parameters, whereas others evaluated IGF-I levels in the seminal fluid or only hormonal profiles. Only few investigations on adult populations considered testicular volumes. ${ }^{140,142,143,145,146}$

\subsection{Endocrine function}

Both LCs and SCs can produce local GH and IGF-I involved in paracrine and autocrine effects.
A recent study conducted using gas chromatography/mass spectrometry revealed that if GHD is associated with hypogonadotropic hypogonadism, it has an additional lowering effect on testosterone, DHT, and E2 levels compared with isolated hypogonadotropic hypogonadism. This finding suggests a synergistic effect of $\mathrm{GH}$ on basal LC function. ${ }^{143}$ From these assumptions, one would expect that $\mathrm{GH}$ therapy would increase testosterone levels. However, the literature in this regard is not univocal.

With regard to $\mathrm{GH}$ therapy, the only studies that showed an increase in testosterone levels included azoospermic ${ }^{140}$ or hypogonadal patients ${ }^{139}$ who were also receiving gonadotropin therapy. Other studies on GHD patients showed no change in total testosterone levels after GH therapy. ${ }^{144,148}$ However, Carani et al, observed that even if total testosterone levels did not change after treatment, CG-stimulated testosterone levels increased after GH therapy compared with baseline. ${ }^{145}$ However, non-GHD patients with oligozoospermia displayed no change in testosterone levels after $\mathrm{GH}$ therapy. ${ }^{138,148}$ Interestingly, in an experimental study on healthy volunteers receiving alternating $\mathrm{rhGH}$ and Pegvisomant therapy, ${ }^{141}$ Andreassen et al reported stable testosterone levels. For completeness, one study with a very small sample size found a reduction of total testosterone levels after $\mathrm{GH}$ therapy in patients with isolated GHD. ${ }^{152}$

As previously reported, E2 rather than testosterone plays a major role in regulating the HPS axis in males, increasing pulsatile GH secretion, ${ }^{44}$ while inhibiting liver IGF-I response at a peripheral level. ${ }^{153}$ In healthy volunteers, GH and IGF-I were positively correlated with serum E2. ${ }^{141}$ In contrast, a placebo-controlled study reported an increase in E2 levels after GH therapy, but no changes were found in $\mathrm{GnRH}$-stimulated gonadotropins, basal or hCG-stimulated androgens, or inhibin B levels. ${ }^{146}$ The authors hypothesized that E2 levels are probably linked to an increase in aromatase activity (both testicular and peripheral). Conversely, males with congenital aromatase deficiency have reduced GH and IGF-I levels. ${ }^{33}$ The central role of E2 in HPS regulation and vice versa is evident even for biological actions, which are traditionally attributed to testosterone in males. In a recent review, starting from the evidence that E2 circulates at higher levels in males than in post-menopausal females, the authors concluded that E2 has a central role in HPG axis regulation and reproductive function in males. ${ }^{42}$

None of the previously cited study reported a change in gonadotropin levels. ${ }^{144-146,148}$ Andreassen et al indicated that AMH levels dropped after $\mathrm{GH}$ treatment in healthy controls, suggesting a maturation effect on SCs probably owing to intratesticular sex steroid syntheses and/or local estrogen increase. ${ }^{141}$

Thus, GH might reduce SHBG concentration by a direct action on liver receptors. Both males with acromegaly $y^{152,154,155}$ and those with obesity with continuous GH infusion ${ }^{156}$ showed low SHBG levels. In contrast, other studies observed no changes in SHBG concentrations after $\mathrm{GH}$ therapy. ${ }^{141,145,146}$

Only few studies described the HPG function in acromegaly: commonly, HPG axis dysfunction is described in both male and female acromegalic patients. ${ }^{65,157,158}$ Although the underlying 
pathophysiology has not been evaluated in detail, possible mechanisms include gonadotropin deficiency, hyperprolactinemia (in mixed $\mathrm{GH} /$ prolactin pituitary adenomas), and tumor mass effect (in macroadenomas). They are therefore mostly indirect mechanism rather than related to $\mathrm{GH}$ excess itself. Males typically show a hypogonadotropic hypogonadal picture with reduced $\mathrm{FSH}$, testosterone, and DHT levels compared with age-matched controls. ${ }^{150,159}$ A decrease in sexual desire together with an impairment of erectile function are frequent findings in patients with active acromegaly. ${ }^{160-162}$ Disease control via somatostatin analogs (or clomiphene) is effective in increasing testosterone and DHT levels in these patients in the short term (6 months), while LH and FSH levels only increase in patients achieving disease control. ${ }^{150}$

\subsection{Reproductive function}

The effect of GH and IGF-I on spermatogenesis is even more intriguing and under-explored than that on endocrine function. IGF-I is secreted by SCs, but IGF-IR is found on SCs themselves, ${ }^{163}$ secondary spermatocytes, spermatids, and spermatozoa. ${ }^{164,165}$ Moreover, IGF-I stimulates sperm maturation and influences sperm motility. ${ }^{166}$

Abnormal sperm parameters seem to correlate with lower serum IGF-I levels but not to seminal plasma IGF-I levels, ${ }^{167}$ implying a more endocrine rather than paracrine function. Shimonovitz et al, reported that azoospermic patients are more likely to have a low $\mathrm{GH}$ response after clonidine administration compared with oligozoospermic and normozoospermic males. ${ }^{168}$ However, other authors reported normal GH and IGF-I levels both in basal condition and after clonidine administration in azoospermic patients affected by either primary or secondary hypogonadism. ${ }^{169}$

A series of prospective intervention studies explored the impact of GH therapy on seminal parameters in infertile males. Some studies confirmed a beneficial effect in patients with fertility problems. Hypogonadotropic hypogonadal patients who failed to respond adequately to conventional treatment showed increased testosterone secretion and improved sperm production and fertility outcomes after $\mathrm{GH}$ cotreatment with gonadotropins. ${ }^{142}$ Infertile males or patients with idiopathic severe oligoasthenoteratozoospermia also displayed an improvement in sperm concentrations, ${ }^{149}$ and asthenozoospermic patients showed an increase in sperm motility. ${ }^{148}$ Unfortunately, these latter studies had a very low sample size.

In contrast, other studies found no influence of $\mathrm{GH}$ replacement in males with hypogonadotropic hypogonadism cotreated with $\mathrm{GH}$ and gonadotropins, ${ }^{138}$ in males with idiopathic oligozoospermia, ${ }^{147}$ or in normogonadotropic patients with severe oligoasthenoteratozoospermia. ${ }^{145}$ Moreover, in a small group of hypogonadotropic hypogonadal azoospermic patients, 6 months of $\mathrm{GH}$ replacement therapy after previous 6 months of gonadotropin treatment, while increasing testicular volume and testosterone levels, failed to induce the appearance of spermatozoa. ${ }^{140}$ Finally, a number of studies showed an increase in seminal volume, suggesting a synergistic effect with testosterone but without improvement in other sperm parameters. ${ }^{140,145,148}$

The only two published studies on semen quality in acromegalic patients report discordant data. In 35 patients with active disease seminal volume, sperm count, total motility (and forward progression), normal morphology, and vitality were all significantly lower than in controls; 6 months of treatment with somatostatin analogs were able to ameliorate sperm number (and total motility in those achieving disease control). Post-treatment IGF-I levels were also found to inversely correlate with total motility, implying a noxious effect of GH/IGF-I excess on spermatogenesis. ${ }^{150}$ More recently, a study on 10 acromegalic men revealed no differences in semen parameters with healthy controls, despite severely reduced serum testosterone and calculated free testosterone levels. ${ }^{170}$ In contrast, hypogonadotropic hypogonadal patients without $\mathrm{GH}$ excess had reduced motile spermatozoa, possibly supporting a positive effect of GH/IGF-I on sperm motility.

\section{5 | CONCLUSIONS}

The evidence reviewed herein supports the existence of a crosstalk between the HPG and HPS axes. Molecular studies confirmed the expressions of both GH and IGF-I receptors at each level of the HPG axis and on reproductive organs. IGF-I signaling may be necessary for GnRH neuron maturation and timely pubertal onset, acting directly and indirectly through kisspeptin neurons and LH-secreting cells. Moreover, a paracrine network of locally produced $\mathrm{GH}$ and IGF-I by LC and SC functions within the testis to produce measurable effects on steroidogenesis and probably with less clear results on spermatogenesis.

In turn, sex hormones regulate HPS activity. First, GH secretion and receptor sensitivity exhibit a clear sex-related pattern. Second, both testosterone and E2 seem to control GH secretion, with E2 apparently being the dominant regulatory hormone at the central level, where it exerts a stimulatory effect, and at the peripheral level, where it inhibits IGF-I production.

The complexity of the interaction is further increased by the emerging role of ghrelin, which is an orexigenic hormone and one of the main drivers of HPS axis activation, but it also inhibits LH secretion, spermatogenesis, and steroidogenesis. Fertility and gonadal maturity strictly depend on metabolic balance and reach their full potential only after the completion of the transition age.

The actual in vivo effects of the somatotropic axis on the reproductive system and sexual organs are not entirely clear, but available literature suggests that physiological levels of activity of the HPS axis are required for proper testicular development from the early stages of fetal development throughout childhood. Insulin growth factors play an essential role in sexual differentiation. Moreover, during minipuberty, IGF-I seems to be decisive for the consolidation 
of the correct testicular position and contributes to linear growth during childhood.

IGF-I actively contributes to GnRH activation, puberty onset, and pubertal pace. Patients with GHD and GHI show delayed puberty and often impaired genital development. In these patients, prompt replacement therapy with $\mathrm{rhGH} / \mathrm{rhIGF}$-I may contribute to timely pubertal onset, correct pubertal development, and achievement of higher testicular volumes and penile lengths compared with controls. IGF-I levels during transition age remain high, even when linear growth is almost completed, suggesting a role in the maturation of the reproductive tract. Lower IGF-I levels in adult males seem to correlate with worse sperm parameters, but no solid evidence is available regarding whether therapy can improve semen characteristics and fertility outcomes in both GHD and idiopathic infertility. Long-term follow-up of GHD patients and studies on infertile males are definitely needed.

The role of GH-IGF-I interactions in sexual maturation and development during puberty and even more during transition age has not received sufficient attention and requires further investigation.

Nevertheless, evaluation of gonadal development in children with GHD is always important to initiate prompt therapy aimed at accurate gonadal maturation. Furthermore, investigation of the function of the HPS axis in children with alterations of the urogenital tract and gonadal development (micropenis, cryptorchidism, and hypospadias) may prove important for therapeutic intervention.

In conclusion, correct diagnosis and prompt therapy are needed for healthier puberty, attainment of complete gonadal development during the transition age, and fertility in adulthood.

\section{ACKNOWLEDGEMENTS}

This study has been proposed and scientifically supported by the Transition and Adolescence Endocrine disease management (TALENT) Study Group, Sapienza University of Rome, Italy.

The authors also wish to thank Massimo Ciafrei for the realization of the figures.

\section{CONFLICT OF INTEREST}

The authors declare no conflicts of interest regarding the publication of this article.

\section{AUTHORS' CONTRIBUTIONS}

All the authors contributed to the conception and design of the review. $\mathrm{MT}, \mathrm{FC}, \mathrm{BC}$, and $\mathrm{GK}$ contributed to revising of literature and acquisition of data. MT, FC, and B.C wrote the first draft, and designed tables and figures. M.T and DG performed a first revision and synthesis of the manuscript. CP and ES were involved in a second critical revision of data. AMI, CK, and DG performed the last critical revision for important intellectual content and final approval of the version to be published. All authors are accountable for the accuracy and integrity of the work; they all reviewed and approved the final manuscript.

\section{ORCID}

Marta Tenuta iD https://orcid.org/0000-0002-7476-0737

Francesco Carlomagno (iD https://orcid.org/0000-0001-5611-4101

Biagio Cangiano iD https://orcid.org/0000-0002-2658-744X

George Kanakis (iD https://orcid.org/0000-0002-3526-8379

Carlotta Pozza (iD https://orcid.org/0000-0002-1147-6114

Emilia Sbardella (D) https://orcid.org/0000-0002-2220-9783

Andrea M. Isidori iD https://orcid.org/0000-0002-9037-5417

Csilla Krausz iD https://orcid.org/0000-0001-6748-8918

Daniele Gianfrilli iD https://orcid.org/0000-0002-2682-8266

\section{REFERENCES}

1. Gnessi L, Fabbri A, Spera G. Gonadal peptides as mediators of development and functional control of the testis: an integrated system with hormones and local environment. Endocr Rev. 1997;18(4):541-609.

2. Chandrashekar V, Zaczek D, Bartke A. The consequences of altered somatotropic system on reproduction. Biol Reprod. 2004;71(1):17-27.

3. Link K, Blizzard RM, Evans WS, Kaiser DL, Parker MW, Rogol AD. The effect of androgens on the pulsatile release and the twentyfour-hour mean concentration of growth hormone in peripubertal males. J Clin Endocrinol Metab. 1986;62(1):159-164.

4. Wennink JM, Delemarre-van de Waal HA, Schoemaker R, Blaauw G, van den Braken C, Schoemaker J. Growth hormone secretion patterns in relation to $\mathrm{LH}$ and estradiol secretion throughout normal female puberty. Acta Endocrinol (Copenh). 1991;124(2):129-135.

5. Rose SR, Municchi G, Barnes KM, et al. Spontaneous growth hormone secretion increases during puberty in normal girls and boys. J Clin Endocrinol Metab. 1991;73(2):428-435.

6. Veldhuis JD, Liem AY, South S, et al. Differential impact of age, sex steroid hormones, and obesity on basal versus pulsatile growth hormone secretion in men as assessed in an ultrasensitive chemiluminescence assay. J Clin Endocrinol Metab. 1995;80(11):3209-3222.

7. D'Ercole AJ, Ye P, Calikoglu AS, Gutierrez-Ospina G. The role of the insulin-like growth factors in the central nervous system. Mol Neurobiol. 1996;13(3):227-255.

8. Daftary SS, Gore AC. Developmental changes in hypothalamic insulin-like growth factor-1: relationship to gonadotropin-releasing hormone neurons. Endocrinology. 2003;144(5):2034-2045.

9. Divall SA, Williams TR, Carver SE, et al. Divergent roles of growth factors in the $\mathrm{GnRH}$ regulation of puberty in mice. J Clin Invest. 2010;120(8):2900-2909.

10. Gutierrez S, Mukdsi JH, Aoki A, Torres Al, Soler AP, Orgnero EM. Ultrastructural immunolocalization of IGF-1 and insulin receptors in rat pituitary culture: evidence of a functional interaction between gonadotroph and lactotroph cells. Cell Tissue Res. 2007;327(1):121-132.

11. Hiney JK, Srivastava VK, Pine MD, Les DW. Insulin-like growth factor-I activates KiSS-1 gene expression in the brain of the prepubertal female rat. Endocrinology. 2009;150(1):376-384.

12. Hashizume T, Kumahara A, Fujino M, Okada K. Insulin-like growth factor I enhances gonadotropin-releasing hormone-stimulated luteinizing hormone release from bovine anterior pituitary cells. Anim Reprod Sci. 2002;70(1-2):13-21.

13. Soldani R, Cagnacci A, Yen SS. Insulin, insulin-like growth factor I (IGF-I) and IGF-II enhance basal and gonadotrophin-releasing hormone-stimulated luteinizing hormone release from rat anterior pituitary cells in vitro. Eur J Endocrinol. 1994;131(6):641-645.

14. Xia YX, Weiss JM, Polack S, Diedrich K, Ortmann O. Interactions of insulin-like growth factor-I, insulin and estradiol with 
GnRH-stimulated luteinizing hormone release from female rat gonadotrophs. Eur J Endocrinol. 2001;144(1):73-79.

15. Baker J, Hardy MP, Zhou J, et al. Effects of an Igf1 gene null mutation on mouse reproduction. Mol Endocrinol. 1996;10(7):903-918.

16. Zhou Y, Xu BC, Maheshwari HG, et al. A mammalian model for Laron syndrome produced by targeted disruption of the mouse growth hormone receptor/binding protein gene (the Laron mouse). Proc Natl Acad Sci USA. 1997;94(24):13215-13220.

17. Qiu X, Dowling AR, Marino JS, et al. Delayed puberty but normal fertility in mice with selective deletion of insulin receptors from Kiss1 cells. Endocrinology. 2013;154(3):1337-1348.

18. Joseph D'Ercole A, Ye P. Expanding the mind: insulin-like growth factor I and brain development. Endocrinology. 2008;149(12):5958-5962.

19. Keene DE, Suescun MO, Bostwick MG, Chandrashekar V, Bartke A, Kopchick JJ. Puberty is delayed in male growth hormone receptor gene-disrupted mice. J Androl. 2002;23(5):661-668.

20. Ramaley JA, Phares CK. Delay of puberty onset in females due to suppression of growth hormone. Endocrinology. 1980;106(6):1989-1993.

21. Vannelli BG, Barni T, Orlando C, Natali A, Serio M, Balboni GC. Insulin-like growth factor-I (IGF-I) and IGF-I receptor in human testis: an immunohistochemical study. Fertil Steril. 1988;49(4):666-669.

22. Cailleau J, Vermeire S, Verhoeven G. Independent control of the production of insulin-like growth factor I and its binding protein by cultured testicular cells. Mol Cell Endocrinol. 1990;69(1):79-89.

23. Spiteri-Grech J, Nieschlag E. The role of growth hormone and insulin-like growth factor $I$ in the regulation of male reproductive function. Horm Res. 1992;38(Suppl 1):22-27.

24. Chatelain PG, Sanchez P, Saez JM. Growth hormone and insulin-like growth factor I treatment increase testicular luteinizing hormone receptors and steroidogenic responsiveness of growth hormone deficient dwarf mice. Endocrinology. 1991;128(4):1857-1862.

25. Wang GM, O'Shaughnessy PJ, Chubb C, Robaire B, Hardy MP. Effects of insulin-like growth factor I on steroidogenic enzyme expression levels in mouse leydig cells. Endocrinology. 2003;144(11):5058-5064.

26. Maran RRM, Sivakumar R, Ravisankar B, et al. Growth hormone directly stimulates testosterone and oestradiol secretion by rat Leydig cells in vitro and modulates the effects of LH and T3. Endocr J. 2000;47(2):111-118.

27. Berensztein EB, Baquedano MS, Pepe CM, et al. Role of IGFs and insulin in the human testis during postnatal activation: differentiation of steroidogenic cells. Pediatr Res. 2008;63(6):662-666.

28. Kanzaki M, Morris PL. Growth hormone regulates steroidogenic acute regulatory protein expression and steroidogenesis in Leydig cell progenitors. Endocrinology. 1999;140(4):1681-1686.

29. Chandrashekar V, Bartke A, Coschigano KT, Kopchick JJ. Pituitary and testicular function in growth hormone receptor gene knockout mice. Endocrinology. 1999;140(3):1082-1088.

30. Vickers MH, Casey PJ, Champion ZJ, Gravance CG, Breier BH. IGF-I treatment increases motility and improves morphology of immature spermatozoa in the $\mathrm{GH}$-deficient dwarf (dw/dw) rat. Growth Horm IGF Res. 1999;9(4):236-240.

31. Veldhuis JD, Metzger DL, Martha PM Jr, et al. Estrogen and testosterone, but not a nonaromatizable androgen, direct network integration of the hypothalamo-somatotrope (growth hormone)-insulin-like growth factor I axis in the human: evidence from pubertal pathophysiology and sex-steroid hormone replacement. J Clin Endocrinol Metab. 1997;82(10):3414-3420.

32. Martha PM Jr, Gorman KM, Blizzard RM, Rogol AD, Veldhuis JD. Endogenous growth hormone secretion and clearance rates in normal boys, as determined by deconvolution analysis: relationship to age, pubertal status, and body mass. J Clin Endocrinol Metab. 1992;74(2):336-344.

33. Rochira V, Zirilli L, Maffei L, et al. Tall stature without growth hormone: four male patients with aromatase deficiency. J Clin Endocrinol Metab. 2010;95(4):1626-1633.

34. Dawson-Hughes B, Stern D, Goldman J, Reichlin S. Regulation of growth hormone and somatomedin- $\mathrm{C}$ secretion in postmenopausal women: effect of physiological estrogen replacement. J Clin Endocrinol Metab. 1986;63(2):424-432.

35. Mauras N, Rogol AD, Veldhuis JD. Increased hGH production rate after low-dose estrogen therapy in prepubertal girls with Turner's syndrome. Pediatr Res. 1990;28(6):626-630.

36. Painson JC, Tannenbaum GS. Sexual dimorphism of somatostatin and growth hormone-releasing factor signaling in the control of pulsatile growth hormone secretion in the rat. Endocrinology. 1991;128(6):2858-2866.

37. Tannenbaum GS, Farhadi-Jou F, Beaudet A. Ultradian oscillation in somatostatin binding in the arcuate nucleus of adult male rats. Endocrinology. 1993;133(3):1029-1034.

38. Gabriel SM, Roncancio JR, Ruiz NS. Growth hormone pulsatility and the endocrine milieu during sexual maturation in male and female rats. Neuroendocrinology. 1992;56(5):619-625.

39. Clark RG, Carlsson LM, Robinson IC. Growth hormone secretory profiles in conscious female rats. J Endocrinol. 1987;114(3):399-407.

40. Udy GB, Towers RP, Snell RG, et al. Requirement of STAT5b for sexual dimorphism of body growth rates and liver gene expression. Proc Natl Acad Sci USA. 1997;94(14):7239-7244.

41. Jaffe CA, Ocampo-Lim B, Guo W, et al. Regulatory mechanisms of growth hormone secretion are sexually dimorphic. J Clin Invest. 1998;102(1):153-164.

42. Russell N, Grossmann M. MECHANISMS IN ENDOCRINOLOGY: Estradiol as a male hormone. Eur J Endocrinol. 2019;181(1):R23-R43.

43. Veldhuis JD, Norman C, Miles JM, Bowers CY. Sex steroids, GHRH, somatostatin, IGF-I, and IGFBP-1 modulate ghrelin's dose-dependent drive of pulsatile GH secretion in healthy older men. J Clin Endocrinol Metab. 2012;97(12):4753-4760.

44. Roelfsema F, Yang RJ, Takahashi PY, Erickson D, Bowers CY, Veldhuis JD. Aromatized Estrogens Amplify Nocturnal Growth Hormone Secretion in Testosterone-Replaced Older Hypogonadal Men. J Clin Endocrinol Metab. 2018;103(12):4419-4427.

45. Avtanski D, Novaira HJ, Wu S, et al. Both estrogen receptor alpha and beta stimulate pituitary GH gene expression. Mol Endocrinol. 2014;28(1):40-52.

46. Rosenbaum M, Gertner JM. Metabolic clearance rates of synthetic human growth hormone in children, adult women, and adult men. J Clin Endocrinol Metab. 1989;69(4):820-824.

47. Juul A, Bang P, Hertel NT, et al. Serum insulin-like growth factor-I in 1030 healthy children, adolescents, and adults: relation to age, sex, stage of puberty, testicular size, and body mass index. J Clin Endocrinol Metab. 1994;78(3):744-752.

48. Landin-Wilhelmsen K, Wilhelmsen L, Lappas G, et al. Serum insulin-like growth factor I in a random population sample of men and women: relation to age, sex, smoking habits, coffee consumption and physical activity, blood pressure and concentrations of plasma lipids, fibrinogen, parathyroid hormone and osteocalcin. Clin Endocrinol (Oxf). 1994;41(3):351-357.

49. Fisker S, Jorgensen JO, Vahl N, Orskov H, Christiansen JS. Impact of gender and androgen status on IGF-I levels in normal and GHdeficient adults. Eur J Endocrinol. 1999;141(6):601-608.

50. Burman P, Johansson AG, Siegbahn A, Vessby B, Karlsson FA. Growth hormone (GH)-deficient men are more responsive to GH replacement therapy than women. J Clin Endocrinol Metab. 1997;82(2):550-555.

51. Johansson AG, Engstrom BE, Ljunghall S, Karlsson FA, Burman P. Gender differences in the effects of long term growth hormone 
(GH) treatment on bone in adults with $\mathrm{GH}$ deficiency. J Clin Endocrinol Metab. 1999;84(6):2002-2007.

52. Tanaka S, Fukuda I, Hizuka N, Takano K. Gender differences in serum GH and IGF-I levels and the GH response to dynamic tests in patients with acromegaly. Endocr J. 2010;57(6):477-483.

53. Fernandez L, Flores-Morales A, Lahuna O, et al. Desensitization of the growth hormone-induced Janus kinase 2 (Jak 2)/signal transducer and activator of transcription 5 (Stat5)-signaling pathway requires protein synthesis and phospholipase C. Endocrinology. 1998;139(4):1815-1824.

54. Vallette S, Serri O. Oral estroprogestin: an alternative low cost therapy for women with postoperative persistent acromegaly? Pituitary. 2010;13(4):311-314.

55. Leong GM, Moverare S, Brce J, et al. Estrogen up-regulates hepatic expression of suppressors of cytokine signaling-2 and -3 in vivo and in vitro. Endocrinology. 2004;145(12):5525-5531.

56. Laron Z, Sarel R. Penis and testicular size in patients with growth hormone insufficency. Acta Endocrinol (Copenh). 1970;63(4):625-633.

57. Laron Z, Mimouni F, Pertzelan A. Effect of human growth hormone therapy on penile and testicular size in boys with isolated growth hormone deficiency: first year of treatment. Isr J Med Sci. 1983;19(4):338-344.

58. Levy JB, Husmann DA. Micropenis secondary to growth hormone deficiency: does treatment with growth hormone alone result in adequate penile growth? J Urol. 1996;156(1):214-216.

59. Becker AJ, Uckert S, Stief CG, et al. Serum levels of human growth hormone during different penile conditions in the cavernous and systemic blood of healthy men and patients with erectile dysfunction. Urology. 2002;59(4):609-614.

60. Hamed EA, Meki AR, Gaafar AA, Hamed SA. Role of some vasoactive mediators in patients with erectile dysfunction: their relationship with angiotensin-converting enzyme and growth hormone. Int J Impot Res. 2003;15(6):418-425.

61. Nguyen AP, Chandorkar A, Gupta C. The role of growth hormone in fetal mouse reproductive tract differentiation. Endocrinology. 1996;137(9):3659-3666.

62. Pollak M. Insulin and insulin-like growth factor signalling in neoplasia. Nat Rev Cancer. 2008;8(12):915-928.

63. Recouvreux MV, Wu JB, Gao AC, et al. Androgen Receptor Regulation of Local Growth Hormone in Prostate Cancer Cells. Endocrinology. 2017;158(7):2255-2268.

64. Colao A, Di Somma C, Spiezia S, Filippella M, Pivonello R, Lombardi G. Effect of growth hormone (GH) and/or testosterone replacement on the prostate in $\mathrm{GH}$-deficient adult patients. $J$ Clin Endocrinol Metab. 2003;88(1):88-94.

65. Colao A, Marzullo P, Spiezia S, et al. Effect of growth hormone $(\mathrm{GH})$ and insulin-like growth factor I on prostate diseases: an ultrasonographic and endocrine study in acromegaly, GH deficiency, and healthy subjects. J Clin Endocrinol Metab. 1999;84(6):1986-1991.

66. Colao A, Marzullo P, Ferone D, et al. Prostatic hyperplasia: an unknown feature of acromegaly. J Clin Endocrinol Metab. 1998;83(3):775-779.

67. Kumar S, Yadav RN, Gupta P, et al. Prostatic hyperplasia in acromegaly, a myth or reality: a case-control study. Eur J Endocrinol. 2015;173(2):X1.

68. Corrêa LL, Lima GAB, Paiva HBdM, et al. Prostate cancer and acromegaly. Arq Bras Endocrinol Metabol. 2009;53(8):963-968.

69. Parolin M, Dassie F, Vettor R, Maffei P. Acromegaly and ultrasound: how, when and why? J Endocrinol Invest. 2020;43(3):279-287.

70. Renehan AG, Zwahlen M, Minder C, O'Dwyer ST, Shalet SM, Egger M. Insulin-like growth factor (IGF)-I, IGF binding protein-3, and cancer risk: systematic review and meta-regression analysis. Lancet. 2004;363(9418):1346-1353.
71. Harrison S, Lennon R, Holly J, et al. Does milk intake promote prostate cancer initiation or progression via effects on insulin-like growth factors (IGFs)? A systematic review and meta-analysis. Cancer Causes Control. 2017;28(6):497-528.

72. Watts EL, Goldacre R, Key TJ, Allen NE, Travis RC, Perez-Cornago A. Hormone-related diseases and prostate cancer: An English national record linkage study. Int J Cancer. 2020;147(3):803-810.

73. Dal J, Leisner MZ, Hermansen $\mathrm{K}$, et al. Cancer Incidence in Patients With Acromegaly: A Cohort Study and Meta-Analysis of the Literature. J Clin Endocrinol Metab. 2018;103(6):2182-2188.

74. Colao A, Marzullo P, Spiezia S, et al. Effect of two years of growth hormone and insulin-like growth factor-I suppression on prostate diseases in acromegalic patients. J Clin Endocrinol Metab. 2000;85(10):3754-3761.

75. Barreiro ML, Suominen JS, Gaytan F, et al. Developmental, stage-specific, and hormonally regulated expression of growth hormone secretagogue receptor messenger RNA in rat testis. Biol Reprod. 2003;68(5):1631-1640.

76. Tena-Sempere M. Exploring the role of ghrelin as novel regulator of gonadal function. Growth Horm IGF Res. 2005;15(2):83-88.

77. Barreiro ML, Gaytan F, Castellano JM, et al. Ghrelin inhibits the proliferative activity of immature Leydig cells in vivo and regulates stem cell factor messenger ribonucleic acid expression in rat testis. Endocrinology. 2004;145(11):4825-4834.

78. Ishikawa T, Fujioka H, Ishimura T, Takenaka A, Fujisawa M. Ghrelin expression in human testis and serum testosterone level. J Androl. 2007;28(2):320-324.

79. Barreiro ML, Gaytan F, Caminos JE, et al. Cellular location and hormonal regulation of ghrelin expression in rat testis. Biol Reprod. 2002;67(6):1768-1776.

80. Di Siena S, Gimmelli R, Nori SL, et al. Activated c-Kit receptor in the heart promotes cardiac repair and regeneration after injury. Cell Death Dis. 2016;7(7):e2317.

81. Vicinanza C, Aquila I, Cianflone E, et al. Kit(cre) knock-in mice fail to fate-map cardiac stem cells. Nature. 2018;555(7697):E1-E5.

82. Caprio M, Isidori AM, Carta AR, Moretti C, Dufau ML, Fabbri A. Expression of functional leptin receptors in rodent Leydig cells. Endocrinology. 1999;140(11):4939-4947.

83. Caprio M, Fabbrini E, Ricci G, et al. Ontogenesis of leptin receptor in rat Leydig cells. Biol Reprod. 2003;68(4):1199-1207.

84. Caprio M, Fabbrini E, Isidori AM, Aversa A, Fabbri A. Leptin in reproduction. Trends Endocrinol Metab. 2001;12(2):65-72.

85. Isidori AM, Caprio M, Strollo F, et al. Leptin and androgens in male obesity: evidence for leptin contribution to reduced androgen levels. J Clin Endocrinol Metab. 1999;84(10):3673-3680.

86. Krausz C, Riera-Escamilla A. Genetics of male infertility. Nat Rev Urol. 2018;15(6):369-384.

87. Pitetti J-L, Calvel P, Romero Y, et al. Insulin and IGF1 receptors are essential for $X X$ and $X Y$ gonadal differentiation and adrenal development in mice. PLoS Genet. 2013;9(1):e1003160.

88. Pitetti J-L, Calvel P, Zimmermann C, et al. An essential role for insulin and IGF1 receptors in regulating sertoli cell proliferation, testis size, and FSH action in mice. Mol Endocrinol. 2013;27(5):814-827.

89. Khan SA, Ndjountche L, Pratchard L, Spicer LJ, Davis JS. Follicle-stimulating hormone amplifies insulin-like growth factor I-mediated activation of AKT/protein kinase B signaling in immature rat Sertoli cells. Endocrinology. 2002;143(6): 2259-2267.

90. Kiviranta P, Kuiri-Hanninen T, Saari A, Lamidi ML, Dunkel L, Sankilampi U. Transient Postnatal Gonadal Activation and Growth Velocity in Infancy. Pediatrics. 2016;138(1).

91. Chellakooty M, Juul A, Boisen KA, et al. A prospective study of serum insulin-like growth factor I (IGF-I) and IGF-binding protein-3 in 942 healthy infants: associations with birth weight, 
gender, growth velocity, and breastfeeding. J Clin Endocrinol Metab. 2006;91(3):820-826.

92. Koskenniemi JJ, Virtanen HE, Wohlfahrt-Veje C, et al. Postnatal Changes in Testicular Position Are Associated With IGF-I and Function of Sertoli and Leydig Cells. J Clin Endocrinol Metab. 2018;103(4):1429-1437.

93. Bondanelli $M$, Ambrosio MR, Margutti $A$, Franceschetti $P$, Zatelli MC, degli Uberti EC. Activation of the somatotropic axis by testosterone in adult men: evidence for a role of hypothalamic growth hormone-releasing hormone. Neuroendocrinology. 2003;77(6):380-387.

94. Prader A, Largo RH, Molinari L, Issler C. Physical growth of Swiss children from birth to 20 years of age. First Zurich longitudinal study of growth and development. Helv Paediatr Acta Suppl. 1989;52:1-125.

95. SbardellaE,PozzaC,IsidoriAM,GrossmanAB.ENDOCRINOLOGY AND ADOLESCENCE: Dealing with transition in young patients with pituitary disorders. Eur J Endocrinol. 2019;181(4):R155 -R171.

96. Juul A, Holm K, Kastrup KW, et al. Free insulin-like growth factor I serum levels in 1430 healthy children and adults, and its diagnostic value in patients suspected of growth hormone deficiency. J Clin Endocrinol Metab. 1997;82(8):2497-2502.

97. Juul A, Flyvbjerg A, Frystyk J, Muller J, Skakkebaek NE. Serum concentrations of free and total insulin-like growth factor-I, IGF binding proteins -1 and -3 and IGFBP- 3 protease activity in boys with normal or precocious puberty. Clin Endocrinol (Oxf). 1996;44(5):515-523.

98. Juul A, Skakkebaek NE. Why Do Normal Children Have Acromegalic Levels of IGF-I During Puberty? J Clin Endocrinol Metab. 2019;104(7):2770-2776.

99. Thankamony A, Ong KK, Ahmed ML, Ness AR, Holly JM, Dunger DB. Higher levels of IGF-I and adrenal androgens at age 8 years are associated with earlier age at menarche in girls. $J$ Clin Endocrinol Metab. 2012;97(5):E786-790.

100. Juul A, Scheike T, Nielsen CT, Krabbe S, Muller J, Skakkebaek NE. Serum insulin-like growth factor I (IGF-I) and IGF-binding protein 3 levels are increased in central precocious puberty: effects of two different treatment regimens with gonadotropin-releasing hormone agonists, without or in combination with an antiandrogen (cyproterone acetate). J Clin Endocrinol Metab. 1995;80(10):3059-3067.

101. Rohayem J, Nieschlag E, Kliesch S, Zitzmann M, Inhibin B. AMH but not INSL3, IGF1 or DHEAS support differentiation between constitutional delay of growth and puberty and hypogonadotropic hypogonadism. Andrology. 2015;3(5):882-887.

102. Lee PA, Mazur T, Houk CP, Blizzard RM. Growth Hormone Deficiency Causing Micropenis: Lessons Learned From a WellAdjusted Adult. Pediatrics. 2018;142(1):e20174168.

103. Castilla-Cortazar I, De Ita JR, Aguirre GA, et al. Growth hormone insensitivity: Mexican case report. Endocrinol Diabetes Metab Case Rep. 2017;2017:17-0216.

104. Urzola A, Leger J, Czernichow P. Three cases of congenital growth hormone deficiency with micropenis and hypospadias: what does growth hormone have to do with it? Horm Res. 1999;51(2):101-104.

105. Amselem S, Duquesnoy $P$, Attree $O$, et al. Laron dwarfism and mutations of the growth hormone-receptor gene. N Engl J Med. 1989;321(15):989-995.

106. Kofoed EM, Hwa V, Little B, et al. Growth hormone insensitivity associated with a STAT5b mutation. N Engl J Med. 2003;349(12):1139-1147.

107. Laron Z, Lilos P, Klinger B. Growth curves for Laron syndrome. Arch Dis Child. 1993;68(6):768-770.

108. Rosenfeld RG, Rosenbloom AL, Guevara-Aguirre J. Growth hormone $(\mathrm{GH})$ insensitivity due to primary $\mathrm{GH}$ receptor deficiency. Endocr Rev. 1994;15(3):369-390.
109. van der Werff ten Bosch JJ, Bot A. Growth of males with idiopathic hypopituitarism without growth hormone treatment. Clin Endocrinol (Oxf). 1990;32(6):707-717.

110. Laron Z, Klinger B. Effect of insulin-like growth factor-I treatment on serum androgens and testicular and penile size in males with Laron syndrome (primary growth hormone resistance). Eur J Endocrinol. 1998;138(2):176-180.

111. Walenkamp MJE, Karperien M, Pereira AM, et al. Homozygous and heterozygous expression of a novel insulin-like growth factor-I mutation. J Clin Endocrinol Metab. 2005;90(5):2855-2864.

112. Begemann M, Zirn B, Santen G, et al. Paternally Inherited IGF2 Mutation and Growth Restriction. N Engl J Med. 2015;373(4):349-356.

113. Gannagé-Yared M-H, Klammt J, Chouery E, et al. Homozygous mutation of the IGF1 receptor gene in a patient with severe preand postnatal growth failure and congenital malformations. Eur J Endocrinol. 2013;168(1):K1-K7.

114. Domené HM, Bengolea SV, Martínez AS, et al. Deficiency of the circulating insulin-like growth factor system associated with inactivation of the acid-labile subunit gene. $N$ Engl $J$ Med. 2004;350(6):570-577.

115. Stanhope R, Albanese A, Hindmarsh P, Brook CG. The effects of growth hormone therapy on spontaneous sexual development. Horm Res. 1992;38(Suppl 1):9-13.

116. Burns EC, Tanner JM, Preece MA, Cameron N. Final height and pubertal development in 55 children with idiopathic growth hormone deficiency, treated for between 2 and 15 years with human growth hormone. Eur J Pediatr. 1981;137(2):155-164.

117. Bourguignon J-P, Vandeweghe $M$, Vanderschueren-lodeweyckx $M$, et al. Pubertal growth and final height in hypopituitary boys: a minor role of bone age at onset of puberty. J Clin Endocrinol Metab. 1986;63(2):376-382.

118. Martinez AS, Heinrich JJ, Rivarola MA, Bergada C. Pubertal development in male hypopituitarism. Eur JPediatr.1986;145(5):384-388.

119. Price DA, Shalet SM, Clayton PE. Management of idiopathic growth hormone deficient patients during puberty. Acta Paediatr Scand Suppl. 1988;347:44-51.

120. Tato L, Zamboni G, Antoniazzi F, Piubello G. Gonadal function and response to growth hormone $(\mathrm{GH})$ in boys with isolated $\mathrm{GH}$ deficiency and to $\mathrm{GH}$ and gonadotropins in boys with multiple pituitary hormone deficiencies. Fertil Steril. 1996;65(4):830-834.

121. Price DA. Puberty in children with idiopathic growth hormone deficiency on growth hormone treatment: preliminary analysis of the data from the Kabi Pharmacia International Growth Study. Acta Paediatr Scand Suppl. 1991;379:117-124.

122. Smuel K, Kauli R, Lilos P, Laron Z. Growth, development, puberty and adult height before and during treatment in children with congenital isolated growth hormone deficiency. Growth Horm IGF Res. 2015;25(4):182-188.

123. Laron Z. Age at first ejaculation (spermarche)-the overlooked milestone in male development. Pediatr Endocrinol Rev. 2010;7(3):256-257.

124. Tanaka T, Yoshizawa A, Tanae A, Hibi I, Shizume K. Relationships between puberty and growth at adolescence in growth-hormone-deficient males: effect of growth hormone and of associated gonadal suppression therapy. Horm Res. 1990;33(Suppl 4):102-105.

125. Rogol AD, Cohen P, Weng W, Kappelgaard AM, Germak JA. Prepubertal children with growth hormone deficiency treated for four years with growth hormone experience dose-dependent increase in height, but not in the rate of puberty initiation. Horm Res Paediatr. 2013;80(1):28-37.

126. Collett-Solberg PF, Ambler G, Backeljauw PF, et al. Diagnosis, Genetics, and Therapy of Short Stature in Children: A Growth Hormone Research Society International Perspective. Horm Res Paediatr. 2019;92(1):1-14. 
127. Kamp GA, Waelkens JJ, de Muinck Keizer-Schrama SM, et al. High dose growth hormone treatment induces acceleration of skeletal maturation and an earlier onset of puberty in children with idiopathic short stature. Arch Dis Child. 2002;87(3):215-220.

128. Kawai M, Momoi T, Yorifuji T, Yamanaka C, Sasaki H, Furusho $K$. Unfavorable effects of growth hormone therapy on the final height of boys with short stature not caused by growth hormone deficiency. J Pediatr. 1997;130(2):205-209.

129. Crowe BJ, Rekers-Mombarg LT, Robling K, et al. Effect of growth hormone dose on bone maturation and puberty in children with idiopathic short stature. J Clin Endocrinol Metab. 2006;91(1):169-175.

130. Albin AK, Ankarberg-Lindgren C, Tuvemo T, et al. Does growth hormone treatment influence pubertal development in short children? Horm Res Paediatr. 2011;76(4):262-272.

131. Leschek EW, Troendle JF, Yanovski JA, et al. Effect of growth hormone treatment on testicular function, puberty, and adrenarche in boys with non-growth hormone-deficient short stature: a randomized, double-blind, placebo-controlled trial. J Pediatr. 2001;138(3):406-410.

132. Rekers-Mombarg LT, Kamp GA, Massa GG, Wit JM. Influence of growth hormone treatment on pubertal timing and pubertal growth in children with idiopathic short stature. Dutch Growth Hormone Working Group. J Pediatr Endocrinol Metab. 1999;12(5):611-622.

133. Bertelloni S, Baroncelli GI, Viacava P, Massimetti M, Simi P, Saggese G. Can growth hormone treatment in boys without growth hormone deficiency impair testicular function? J Pediatr. 1999;135(3):367-370.

134. Ankarberg-Lindgren C, Norjavaara E, Wikland KA. Short boys treated with growth hormone show normal progression of testicular size and achieve normal serum testosterone concentrations. Eur J Endocrinol. 2002;146(5):681-685.

135. Radicioni AF, Paris E, De Marco E, Anzuini A, Gandini L, Lenzi A. Testicular function in boys previously treated with recombinant-human growth hormone for non-growth hormone-deficient short stature. J Endocrinol Invest. 2007;30(11):931-936.

136. Grimberg A, DiVall SA, Polychronakos C, et al. Guidelines for Growth Hormone and Insulin-Like Growth Factor-I Treatment in Children and Adolescents: Growth Hormone Deficiency, Idiopathic Short Stature, and Primary Insulin-Like Growth Factor-I Deficiency. Horm Res Paediatr. 2016;86(6):361-397.

137. Anapliotou MG, Evagellou E, Kastanias I, Liparaki M, Psara P, Goulandris N. Effect of growth hormone cotreatment with human chorionic gonadotropin in testicular steroidogenesis and seminal insulin-like growth factor-1 in oligozoospermia. Fertil Steril. 1996;66(2):305-311.

138. Zalel Y, Draysen E, Goldschmit R, Zadik Z, Shoham Z. A prospective pilot study of co-treatment with growth hormone and gonadotropins for improving spermatogenesis in normogonadotropic patients with severe oligoteratoasthenospermia. Gynecol Endocrinol. 1996;10(1):23-28.

139. Balducci R, Toscano V, Mangiantini A, Bianchi P, Guglielmi R, Boscherini B. The effect of growth hormone administration on testicular response during gonadotropin therapy in subjects with combined gonadotropin and growth hormone deficiencies. Acto Endocrinol (Copenh). 1993;128(1):19-23.

140. Giagulli VA. Absence of effect of recombinant growth hormone to classic gonadotropin treatment on spermatogenesis of patients with severe hypogonadotropic hypogonadism. Arch Androl. 1999;43(1):47-53.

141. Andreassen M, Frystyk J, Faber J, Kristensen LO, Juul A. Growth hormone $(\mathrm{GH})$ activity is associated with increased serum oestradiol and reduced anti-Mullerian hormone in healthy male volunteers treated with $\mathrm{GH}$ and a $\mathrm{GH}$ antagonist. Andrology. 2013;1(4):595-601.
142. Shoham Z, Conway GS, Ostergaard H, Lahlou N, Bouchard P, Jacobs HS. Cotreatment with growth hormone for induction of spermatogenesis in patients with hypogonadotropic hypogonadism. Fertil Steril. 1992;57(5):1044-1051.

143. Giton F, Trabado S, Maione L, et al. Sex steroids, precursors, and metabolite deficiencies in men with isolated hypogonadotropic hypogonadism and panhypopituitarism: a GCMS-based comparative study. J Clin Endocrinol Metab. 2015;100(2):E292-296.

144. Hubina E, Mersebach H, Rasmussen ÅK, et al. Effect of growth hormone replacement therapy on pituitary hormone secretion and hormone replacement therapies in GHD adults. Horm Res. 2004;61(5):211-217.

145. Carani C, Granata AR, De Rosa M, et al. The effect of chronic treatment with $\mathrm{GH}$ on gonadal function in men with isolated $\mathrm{GH}$ deficiency. Eur J Endocrinol. 1999;140(3):224-230.

146. Juul A, Andersson AM, Pedersen SA, et al. Effects of growth hormone replacement therapy on IGF-related parameters and on the pituitary-gonadal axis in $\mathrm{GH}$-deficient males. A double-blind, placebo-controlled crossover study. Horm Res. 1998;49(6):269-278

147. Lee K-O, Ng S-C, Lee P-S, et al. Effect of growth hormone therapy in men with severe idiopathic oligozoospermia. Eur J Endocrinol. 1995;132(2):159-162.

148. Ovesen P, Lunde Jørgensen JO, Ingerslev J, Ho KKY, Ørskov H, Christiansen JS. Growth hormone treatment of subfertile males** Supported by Novo Nordisk, Gentofte, Denmark. Fertil Steril. 1996;66(2):292-298

149. Radicioni A, Paris E, Dondero F, Bonifacio V, Isidori A. Recombinantgrowth hormone (rec-hGH) therapy in infertile men with idiopathic oligozoospermia. Acta Eur Fertil. 1994;25(5):311-317.

150. Colao A, De Rosa M, Pivonello R, et al. Short-term suppression of $\mathrm{GH}$ and IGF-I levels improves gonadal function and sperm parameters in men with acromegaly. J Clin Endocrinol Metab. 2002;87(9):4193-4197.

151. Bartke A, Chandrashekar V, Bailey B, Zaczek D, Turyn D. Consequences of growth hormone $(\mathrm{GH})$ overexpression and $\mathrm{GH}$ resistance. Neuropeptides. 2002;36(2-3):201-208.

152. Giavoli C, Ferrante E, Ermetici F, et al. Effect of recombinant $\mathrm{hGH}(\mathrm{rhGH})$ replacement on gonadal function in male patients with organic adult-onset $\mathrm{GH}$ deficiency. Clin Endocrinol (Oxf). 2006;65(6):717-721.

153. Leung KC, Doyle N, Ballesteros M, et al. Estrogen inhibits GH signaling by suppressing $\mathrm{GH}$-induced JAK2 phosphorylation, an effect mediated by SOCS-2. Proc Natl Acad Sci USA. 2003;100(3):1016-1021.

154. Anderson DC. Sex-hormone-binding globulin. Clin Endocrinol (Oxf). 1974;3(1):69-96.

155. De Moor P, Heyns W, Bouillon R. Growth hormone and the steroid binding -globulin of human plasma. J Steroid Biochem. 1972;3(3):593-600

156. Oscarsson J, Lindstedt G, Lundberg PA, Eden S. Continuous subcutaneous infusion of low dose growth hormone decreases serum sex-hormone binding globulin and testosterone concentrations in moderately obese middle-aged men. Clin Endocrinol (Oxf). 1996;44(1):23-29.

157. Melmed S, Ho K, Klibanski A, Reichlin S, Thorner M. Clinical review 75: Recent advances in pathogenesis, diagnosis, and management of acromegaly. J Clin Endocrinol Metab. 1995;80(12):3395-3402.

158. Katznelson L, Kleinberg D, Vance ML, et al. Hypogonadism in patients with acromegaly: data from the multi-centre acromegaly registry pilot study. Clin Endocrinol (Oxf). 2001;54(2):183-188.

159. Duarte FH, Jallad RS, Bronstein MD. Clomiphene citrate for treatment of acromegaly not controlled by conventional therapies. J Clin Endocrinol Metab. 2015;100(5):1863-1869.

160. Lotti F, Rochira V, Pivonello R, et al. Erectile Dysfunction is Common among Men with Acromegaly and is Associated with Morbidities Related to the Disease. J Sex Med. 2015;12(5):1184-1193. 
161. Galdiero M, Pivonello R, Grasso LFS, Cozzolino A, Colao A. Growth hormone, prolactin, and sexuality. J Endocrinol Invest. 2012;35(8):782-794.

162. Raju JA, Shipman KE, Inglis JA, Gama R. Acromegaly Presenting as Erectile Dysfunction: Case Reports and Review of the Literature. Rev Urol. 2015;17(4):246-249.

163. Borland K, Mita M, Oppenheimer CL, et al. The actions of insulin-like growth factors I and II on cultured Sertoli cells. Endocrinology. 1984;114(1):240-246.

164. Tres LL, Smith EP, Van Wyk JJ, Kierszenbaum AL. Immunoreactive sites and accumulation of somatomedin-C in rat Sertolispermatogenic cell co-cultures. Exp Cell Res. 1986;162(1):33-50.

165. NazRK, Padman P. Identification of insulin-like growth factor (IGF)-1 receptor in human sperm cell. Arch Androl. 1999;43(2):153-159.

166. Glander HJ, Kratzsch J, Weisbrich C, Birkenmeier G. Insulin-like growth factor-I and alpha 2-macroglobulin in seminal plasma correlate with semen quality. Hum Reprod. 1996;11(11):2454-2460.

167. Lee HS, Park YS, Lee JS, Seo JT. Serum and seminal plasma insulin-like growth factor-1 in male infertility. Clin Exp Reprod Med. 2016;43(2):97-101.
168. Shimonovitz S, Zacut D, Ben Chetrit A, Ron M. Growth hormone status in patients with maturation arrest of spermatogenesis. Hum Reprod. 1993;8(6):919-921.

169. Carani C, Mantovani R, Procopio M, Del Rio G, Rossetto R, Granata AR. GH/IGF-I axis in azoospermia in primary and secondary hypogonadism: a study before and during replacement therapy. Int $J$ Androl. 1999;22(3):184-189.

170. Andreassen $M$, Juul $A$, Feldt-Rasmussen $U$, Jorgensen $N$. Semen quality in hypogonadal acromegalic patients. Pituitary. 2020;23(2):160-166.

How to cite this article: Tenuta M, Carlomagno F, Cangiano $\mathrm{B}$, et al. Somatotropic-Testicular Axis: A crosstalk between GH/IGF-I and gonadal hormones during development, transition, and adult age. Andrology. 2020;00:1-17. https:// doi.org/10.1111/andr.12918 